\title{
PENENTUAN JENIS TUMBUHAN LOKAL DALAM UPAYA MITIGASI LONGSOR DAN TEKNIK BUDIDAYANYA PADA AREAL RAWAN LONGSOR DI KPH LAWU DS: Studi Kasus di RPH Cepoko
}

\author{
Determination of Local Plants Species in Mitigation Effort at Areas Prone and Cultivation \\ Techniques in KPH Lawu Ds: Case Study in RPH Cepoko
}

\author{
Fibo Adhitya ${ }^{1}$, Omo Rusdiana ${ }^{1}$, dan Muhammad Buce Saleh ${ }^{2}$ \\ ${ }^{1}$ Departemen Silvikultur, Fakultas Kehutanan IPB; ${ }^{2}$ Departemen Manajemen Hutan, Fakultas Kehutanan IPB \\ Institut Pertanian Bogor, Jl Lingkar Akademik Kampus IPB Darmaga PO BOX 168, Bogor 16680. \\ Telp (0251) 8626806, Fax (0251) 8626886
}

\begin{abstract}
Natural disasters that occur in most areas of Indonesia would certainly give rise to a wide range of impacts on the physical, social, and economic life of the society. One of these natural disasters is landslides. KPH Lawu Ds is a owned company Perhutani, which produces pine resin. KPH area Lawu Ds are generally located in areas that have a steep slope has an area prone to landslides are quite extensive. Therefore, in carrying out forest cultivation of plants which are generally homogenous need additional types of vegetation can reduce the level of vulnerability to landslides. Landslides can also be regarded as a form of land use that have little or no attention to soil conservation techniques, but in this study only look from the vegetation in developing soil conservation techniques in homogeneous plantation forests in the forest management unit areas KPH Lawu Ds. Therefore, the purpose of this study was to obtain the right local plant species as the plant are prioritized and appropriate to prevent the occurrence of landslides and obtain the shape and pattern of cultivation. Data analysis using descriptive analysis of qualitative and models that fit the preferences of local preferences of plants grown on land prone to landslides in RPH Cepoko by using the method of AHP (Analytical Hierarchy Process). Alternatives are obtained based on the plants prioritized is clove, coffee, chocolate, calliandra, Leucaena leucocephala, durian, Swietenia macrophylla, Aleuriteus Moluccana, Paraserianthes falcataria, Pangium edule, Anacardium occidentale, and Sterculia foetida and cultivation techniques of forest vegetation on the sides of the plant adjusted based onsolum soil, slope and vegetation cover of pine with dense composition, middle and rare on research plots in the area of KPH Lawu Ds and planting distance is determined by the density of the canopy.
\end{abstract}

Key words: mitigation, native plant species, preference, cultivation techniques.

\section{PENDAHULUAN}

Gerakan tanah atau yang lebih dikenal dengan istilah tanah longsor adalah proses bergeraknya suatu massa tanah dan batuan dalam jumlah yang besar menuju ke tempat yang lebih rendah. Menurut Dibyosaputro (1999), gerakan massa atau longsor adalah proses bergeraknya puing-puing batuan (termasuk tanah di dalamnya) secara besar-besaran menuruni lereng secara lambat hingga cepat oleh pengaruh langsung dari gravitasi. Gaya yang menahan massa tanah di sepanjang lereng tersebut dipengaruhi oleh sifat fisik tanah dan sudut dalam tahanan geser tanah yang bekerja di sepanjang lereng. Dampak kerusakannya antara lain berupa berubahnya permukaan tanah serta hilangnya tanah lapisan atas dan vegetasi (Kurnia et al. 2005).

Vegetasi merupakan faktor penting dalam menjaga kemantapan lereng, karena ketiadaan tumbuhan atau pepohonan di daerah pegunungan akan sangat mempengaruhi proses longsor. Menurut Asdak (2003), pengaruh vegetasi penutup tanah adalah untuk melindungi permukaan tanah dari tumbukan air hujan, menurunkan kecepatan dan volume air larian, menahan partikel-pertikel tanah pada tempatnya melalui sistem perakaran dan serasah yang dihasilkan dan mempertahankan kemantapan kapasitas tanah dalam menyerap air. Adanya vegetasi penutup tanaman yang baik seperti rumput yang tebal atau hutan yang lebat dapat menghilangkan pengaruh topografi terhadap erosi yang akan berakibat pada terjadinya longsor.

Tumbuhan yang menutup permukaan tanah secara rapat tidak saja memperlambat limpasan, tetapi juga dapat menghambat pengangkutan partikel tanah. Disamping itu akar tumbuhan juga berfungsi untuk mengikat butir-butir tanah sekaligus menjaga pori-pori tanah dibawahnya, sehingga infiltrasi air hujan berjalan dengan lancar.

Kesatuan Pemangku Hutan (KPH) Lawu Ds merupakan salah satu unit kelola milik Perum Perhutani Divisi Regional II Jawa Timur yang memproduksi getah pinus. Berdasarkan posisi administrasi, wilayah $\mathrm{KPH}$ Lawu Ds terletak di lima Kabupaten yaitu Kabupaten Ngawi, Magetan, Madiun, Ponorogo, dan Pacitan. Kabupaten Ponorogo merupakan daerah yang sering 
mengalami longsor. Berdasarkan data dan informasi tanah longsor di Ponorogo tahun 2006 sampai dengan 2015, kejadian tanah longsor tersebut telah terjadi di 9 kecamatan dan 18 desa dengan jenis kerusakan meliputi 86 rumah mengalami kerusakan, 1609 jembatan ambruk, dan sepanjang $0.115 \mathrm{Km}$ jalanan rusak (BNPB 2015).

Lokasi petak tanam yang berada di daerah pegunungan rentan dengan ancaman erosi dan longsor (Priyono 2010). Oleh karena itu, Areal KPH Lawu Ds yang umumnya berada pada areal yang mempunyai kelerengan yang curam memiliki luas area rawan longsor yang cukup luas. Dengan demikian dalam rangka mengantisipasi bahaya longsor diperlukan upaya-upaya mitigasi antara lain melalui pemilihan jenis tumbuhan dan pola tanam yang dapat mengurangi resiko longsor.

Tujuan penelitian ini adalah untuk mendapatkan jenis tumbuhan lokal prioritas yang tepat dalam upaya pencegahan dan mitigasi longsor di kawasan rawan longsor KPH Lawu Ds berdasarkan persepsi masyarakat dan petugas KPH Lawu Ds, serta memperoleh bentuk dan pola budidayanya. Hasil penelitian ini diharapkan juga dapat memberikan informasi bagi KPH Lawu Ds tentang teknik mitigasi longsor dengan menggunakan tumbuhan untuk mengembangkan teknik konservasi tanah dari sisi vegetasi di hutan tanaman homogen di wilayah KPH Lawu Ds.

\section{BAHAN DAN METODE}

\section{Lokasi dan Waktu Penelitian}

Penelitian dilaksanakan pada bulan Agustus hingga September 2015 di kawasan Perhutani Divisi Regional II Jawa Timur; KPH Lawu DS, RPH Cepoko, Desa Cepoko, Kecamatan Ngrayun, Kabupaten Ponorogo. Pemilihan kasus dilakukan secara purposive sampling yaitu berdasarkan kejadian longsor dan potensi rawan longsor pada petak nomor 5B3, 39C1, 54A, 66B, dan 69A2.

\section{Bahan dan Alat}

Bahan yang diteliti adalah data preferensi jenis tumbuhan yang berpotensi mencegah longsor menurut masyarakat dan RPH Cepoko.

Alat yang digunakan adalah kamera digital, tally sheet, alat tulis, plastik sampel, label, kuesioner dan seperangkat komputer yang dilengkapi dengan software: Microsoft Word dan Expert Choice 2000.

\section{Metode Kerja}

\section{Kajian literatur}

Tahap ini terdiri dari tahap identifikasi faktor-faktor yang menyebabkan terjadinya tanah longsor. Penelitian ini hanya terbatas pada 6 faktor utama yang sangat berperan dalam menyebabkan terjadinya tanah longsor yang terdiri dari kemiringan lereng, kerapatan vegetasi, jenis tanah, tekstur tanah, solum tanah, dan relief.
Pada tahap ini dilakukan juga pengambilan data berupa data kondisi umum lokasi penelitian seperti, letak dan luas areal, keadaan umum, data biofisik serta kondisi tapak KPH Lawu Ds, RPH Cepoko, dan informasi data tanah longsor dari BNPB tahun 2006 sampai dengan 2015 yang menunjukkan kawasan longsor di daerah Ponorogo.

Data tumbuhan diperoleh dari berbagai sumber pustaka, bahwa tumbuhan yang sesuai untuk mitigasi longsor adalah tumbuhan yang memiliki ciri-ciri tipe perakaran dalam, transpirasi tinggi, dan tidak berpotensi mengikat air, sedangkan pola tanam yang sesuai untuk mitigasi yang diperoleh dari berbagai sumber pustaka dapat disusun berdasarkan jarak tanam dan kerapatan tajuk.

\section{Peninjauan lapangan}

Pada tahap ini dilakukan survei daerah yang telah ditentukan dan diikuti dengan pengumpulan data profil longsor. Pada lokasi longsor juga dilihat tipe penggunaan lahan dan juga tingkat kerapatan vegetasinya. Selain itu diambil foto lokasi yang belum terjadi longsor (rawan longsor) dan yang terjadi longsor. Untuk yang terjadi longsor diamati lintasan longsorannya dan dicocokkan berdasarkan berbagai sumber pustaka berupa gambar deskriptif atau foto kejadian longsor.

Data tumbuhan diperoleh dengan meminta responden atau masyarakat untuk menunjukkan secara langsung tumbuhan yang dimaksud dan juga dilakukan kegiatan wawancara. Data pola tanam diperoleh dengan melihat budidaya tanaman yang dikelola oleh masyarakat di sekitar petak penelitian.

\section{Wawancara mendalam atau wawancara terpandu}

Kegiatan wawancara dilakukan kepada stakeholders yang berwenang untuk mendapatkan data dan informasi yang tepat terkait jenis tanaman lokal yang tepat sebagai tanaman yang diprioritaskan untuk kegiatan mitigasi longsor. Adapun kelompok masyarakat yang diwawancara antara lain:

1. Masyarakat Desa di sekitar atau di dalam kawasan RPH Cepoko dekat kawasan rawan longsor, sebanyak 50 orang responden yang menjadi anggota LMDH Tani rukun dan LMDH Agro raya dengan cara purposive sampling.

2. Staf Perhutani Divisi Regional II Surabaya, KPH Lawu Ds dan BKPH sebanyak 4 orang responden yang terdiri dari, Asisten Perhutani (Asper), KRPH Cepoko, KRPH Bungkal, dan KRPH Pulung dengan cara purposive sampling.

Kuesioner yang digunakan berupa daftar pertanyaan dan jawaban, serta pilihan berganda. Kuesioner tersebut dikelompokan menjadi dua bagian sebagai representasi respodennya, yaitu:

1. Kuesioner teknis yang digunakan dalam survei lapangan dan wawancara kepada responden ketua LMDH Tani rukun dan LMDH Agro raya, serta pesanggrem yang menjadi anggota LMDH Tani rukun dan LMDH Agro raya. Kuesioner ini digunakan untuk memperoleh gambaran umum 
kondisi lokasi dan masukan mengenai jenis tumbuhan lokal yang tepat sebagai tanaman yang diprioritaskan untuk kegiatan mitigasi longsor secara vegetatif.

2. Kuesioner pakar digunakan dalam survei pakar, yaitu kepada Asisten Perhutani (Asper), KRPH Cepoko, KRPH Bungkal, dan KRPH Pulung. Kuesioner ini digunakan untuk memperoleh data yang memberikan gambaran mengenai hubungan kontekstual dan level hierarki elemen-elemen model jenis tanaman lokal yang tepat sebagai tanaman yang diprioritaskan untuk kegiatan mitigasi longsor secara vegetatif.

\section{Analisis Data}

a) Melakukan identifikasi jenis dan sebaran longsor di RPH Cepoko

Menggunakan analisis deskriptif untuk menggambarkan dan mengidentifikasi jenis longsor pada masing-masing petak tanam. Peubah yang dianalisa antara lain jenis longsoran, karakter biofisik di masingmasing petak tanam, karakter tapak di masing-masing petak tanam, usaha pencegahan longsor, dan pengelolaan.

b) Menggali prioritas jenis tumbuhan lokal berdasarkan preferensi masyarakat dan staf KPH Lawu Ds di lingkungannya

Menggunakan analisis deskriptif yaitu menggambarkan jenis tumbuhan lokal berdasarkan hasil wawancara dengan masyarakat. Peubah yang dianalisa antara lain jenis tumbuhan lokal, dan habitus jenis tumbuhan lokal tersebut.

c) Mengkaji teknik budidaya dan faktor pembatas tanaman

Menggunakan analisis deskriptif untuk menggambarkan teknik budidaya di masing-masing petak tanam dan faktor pembatas tanaman. Peubah yang dianalisa antara lain karakter biofisik di masing-masing petak tanam, karakter tapak di masing-masing petak tanam, dan teknik budidaya yang sesuai untuk diterapkan RPH Cepoko.

d) Mengkaji pola tanam dan jarak tanam untuk kegiatan mitigasi longsor

Menggunakan analisis deskriptif untuk mengambarkan pola tanam dan jarak tanam. Peubah yang dianalisa antara lain karakter biofisik di masingmasing petak tanam, karakter tapak di masing-masing petak tanam, dan teknik budidaya yang sesuai untuk diterapkan di RPH Cepoko.

e) Analisis preferensi jenis tumbuhan lokal untuk kegiatan mitigasi longsor

Membuat model preferensi tumbuhan lokal dibangun dengan menggunakan metode AHP (Analytical Hierarchy Process) dengan model rating yang bertujuan mendapatkan pilihan prioritas tumbuhan lokal untuk kegiatan mitigasi longsor. Tujuannya adalah mendapatkan jenis tumbuhan untuk mitigasi longsor. Kriteria yang digunakan adalah berdasarkan aspek ekologi, ekonomi, dan sosial; sedangkan untuk indikator dari setiap kriteria meliputi:

1. Ekologi: tumbuhan yang sesuai dengan manajemen KPH Lawu Ds.

2. Ekonomi: tumbuhan yang berharga jika dijual, mudah dipasarkan, dan bersifat multi manfaat.

3. Sosial: Tumbuhan yang disukai masyarakat, dan masyakat menguasai cara budidayanya.

\section{HASIL DAN PEMBAHASAN}

\section{Jenis dan Sebaran Longsor}

Jenis longsoran dibedakan berdasarkan lokasi penelitian yang belum terjadi longsor (rawan longsor) dan yang terjadi longsor. Pada petak 54A, 66B, dan 69A2 tidak terjadi longsor tetapi cenderung berpotensi longsor. Longsor terjadi di petak tanam 35B3 dan 39C1. Pada kejadian longsor tersebut, karakteristik longsor yang ditemui adalah longsoran aliran bahan rombakan untuk kejadian longsor di petak tanam nomor 35B3 dan longsoran rotasi (Slump) untuk kejadian longsor di petak tanam nomor 39C1.

Berdasarkan Tabel 1 dan Tabel 2, tanah di lokasi penelitian umumnya bertekstur lempung (Clay), tanah ini mengandung garam mineral, apabila garam mineral tersebut larut oleh aliran air tanah atau oleh infiltrasi air hujan; dapat mereduksi kekuatan gaya gesernya dan menyebabkan terjadinya longsor. Kelerengan di lima lokasi penelitian berkisar dari $14 \%$ sampai $60 \%$ dengan relief landai sampai dengan sangat curam. Lokasi penelitian yang bertekstur lempung (Clay) ikut mempengaruhi kestabilan lereng. Stabilnya lereng didasarkan pada banyak atau tidaknya air yang meresap di dalam lereng.

Bidang miring pada pertemuan antara tanah yang terletak di permukaan lereng dengan yang banyak batuan seperti pada petak 35B3 berpotensi menjadi bidang gelincir dari tanah yang akan longsor, pada bagian tersebut tahanan tanah dalam menahan gesekan lebih rendah. Disamping itu, air hujan yang berinfiltrasi ke dalam tanah yang lolos air, berakumulasi di atas batuan dan membentuk zona genangan air yang merembes ke bawah, apabila terjadi terus menerus akan berpengaruh dan menyebabkan peristiwa pelunakan kaki lereng yang akan menambah beban tanah dan berakibat longsor. Jarak tanam yang lebar (kerapatan vegetasi yang rendah) memberikan kesempatan lebih besar kepada sinar matahari dan air hujan untuk mencapai permukaan tanah sehingga proses pelapukan fisik semakin intensif dan lebih mendorong terjadinya longsor.

Longsoran rotasi (slump) adalah bergeraknya sejumlah massa tanah dan batuan pada bidang gelincir berbentuk cekung (Gambar 1). Longsoran ini dipengaruhi oleh tanah bertekstur lempung. Tanah dengan tekstur ini mudah mengembang dan susut, dimana material tersebut mengembang pada saat basah dan menyusut pada saat kering dan pada saat pengglinciran membentuk lintasan melengkung dan massa tanah bergerak bersama dalam satu kesatuan di sepanjang bidang longsoran atau bidang glincir yang relatif tipis. 
Tabel 1 Karakter biofisik serta kondisi tapak petak pengamatan yang rawan longsor.

\begin{tabular}{|c|c|c|c|c|c|c|c|c|}
\hline Petak & $\begin{array}{c}\text { Tutupan } \\
\text { Vegetasi Pinus }\end{array}$ & $\begin{array}{c}\text { Jenis } \\
\text { Tanah }\end{array}$ & $\begin{array}{l}\text { Tekstur } \\
\text { Tanah }\end{array}$ & $\begin{array}{l}\text { Solum } \\
\text { Tanah }\end{array}$ & Batuan & Relief & $\begin{array}{c}\text { Kelerengan } \\
(\%)\end{array}$ & $\begin{array}{l}\text { Jarak } \\
\text { tanam }\end{array}$ \\
\hline $54 \mathrm{~A}$ & Rapat & Latosol & $\begin{array}{c}\text { Lempung } \\
\text { Berpasir } \\
\text { (Sandy } \\
\text { clay) }\end{array}$ & Dangkal & $\begin{array}{l}\text { Sedikit } \\
\text { batu }\end{array}$ & Curam & 45 & $\begin{array}{l}\text { Tumbuh } \\
\text { alami }\end{array}$ \\
\hline $66 B$ & Rapat & Latosol & $\begin{array}{c}\text { Lempung } \\
\text { Berpasir } \\
\text { (Sandy } \\
\text { clay) }\end{array}$ & Sedang & $\begin{array}{l}\text { Sedikit } \\
\text { batu }\end{array}$ & $\begin{array}{l}\text { Sangat } \\
\text { curam }\end{array}$ & 60 & $\begin{array}{l}\text { Tumbuh } \\
\text { alami }\end{array}$ \\
\hline 69A2 & Jarang & Latosol & $\begin{array}{l}\text { Lempung } \\
\text { (Clay) }\end{array}$ & Sedang & $\begin{array}{l}\text { Sedikit } \\
\text { batu }\end{array}$ & Landai & 14 & $3 \times 2$ \\
\hline
\end{tabular}

Sumber: Hasil pengamatan dan data biofisik serta kondisi tapak RPH Cepoko 2015.

Tabel 2 Karakter biofisik serta kondisi tapak petak pengamatan yang longsor.

\begin{tabular}{|c|c|c|c|c|c|c|c|c|}
\hline Petak & $\begin{array}{c}\text { Tutupan } \\
\text { Vegetasi } \\
\text { Pinus } \\
\end{array}$ & $\begin{array}{c}\text { Jenis } \\
\text { Tanah }\end{array}$ & $\begin{array}{l}\text { Tekstur } \\
\text { Tanah }\end{array}$ & $\begin{array}{l}\text { Solum } \\
\text { Tanah }\end{array}$ & Batuan & Relief & $\begin{array}{c}\text { Kelerengan } \\
(\%)\end{array}$ & Jarak tanam \\
\hline $35 \mathrm{B3}$ & Kosong & Latosol & $\begin{array}{c}\text { Lempung } \\
\text { (Clay) }\end{array}$ & Dangkal & $\begin{array}{c}\text { Banyak } \\
\text { batu }\end{array}$ & $\begin{array}{l}\text { Sangat } \\
\text { curam }\end{array}$ & 51 & - \\
\hline $39 \mathrm{C} 1$ & Jarang & Latosol & $\begin{array}{c}\text { Lempung } \\
\text { (Clay) }\end{array}$ & Sedang & $\begin{array}{c}\text { Sedikit } \\
\text { batu }\end{array}$ & Curam & 31 & $4 \times 4$ \\
\hline
\end{tabular}

Sumber: Hasil pengamatan dan data biofisik serta kondisi tapak RPH Cepoko 2015.
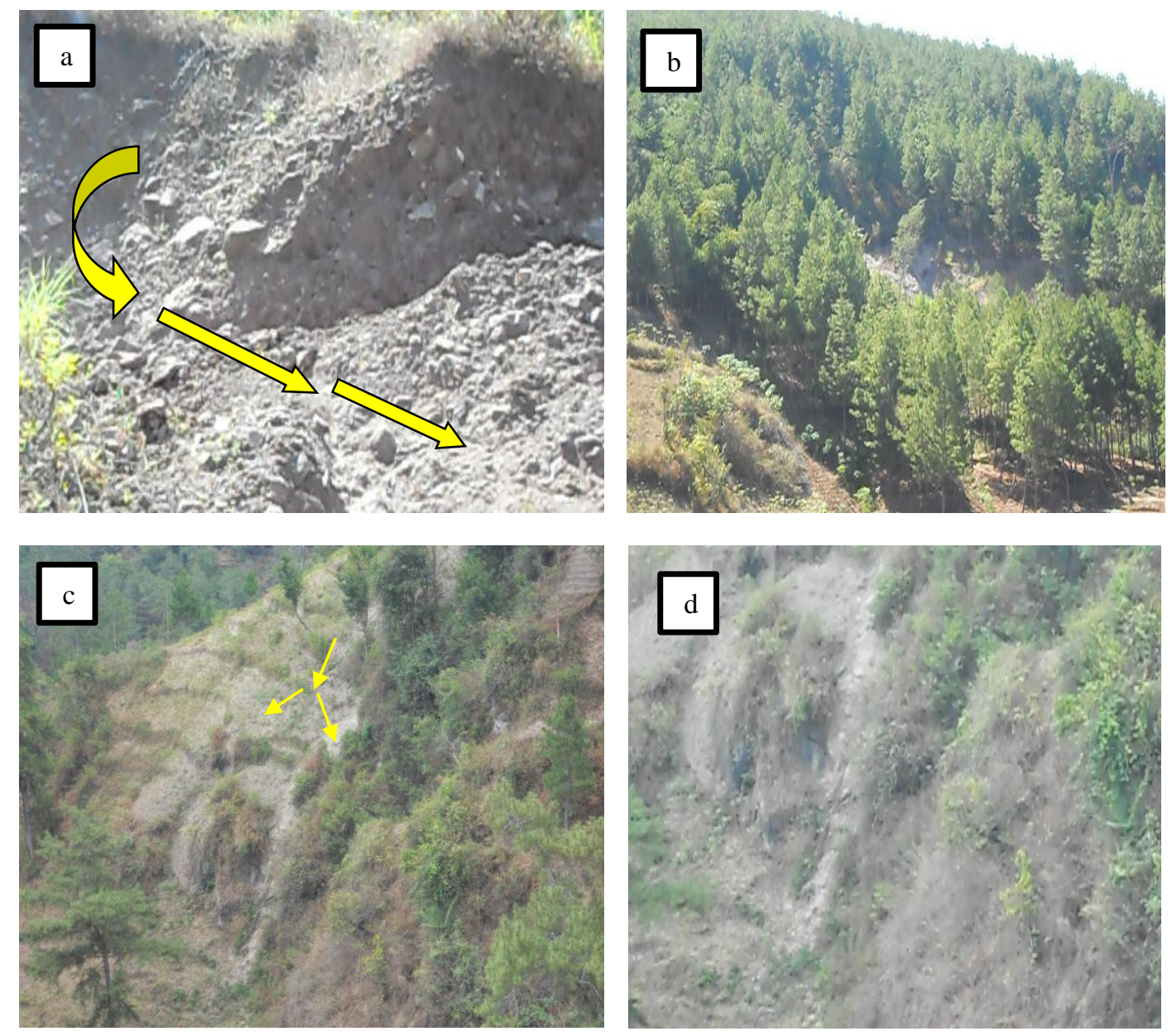

Gambar 1 Longsor di petak tanam 35B3 dan 39C: (a) Longsoran di petak 39C1; membentuk lintasan melengkung; (b) Tutupan vegetasi pinus dengan kondisi jarang; (c) Longsoran aliran bahan rombakan di petak 35B3; membentuk lintasan aliran ke sisi kanan dan kiri; (d) Tutupan vegetasi pinus berupa lahan kosong yang ditumbuhi rumput dan semak belukar 
Tabel 3 Penanggulangan bencana longsor di lima petak pengamatan

\begin{tabular}{|c|c|c|c|c|c|c|c|c|}
\hline \multirow[b]{2}{*}{ Lokasi } & \multirow[b]{2}{*}{$\begin{array}{c}\text { Klasifikasi } \\
\text { Hutan } \\
\text { PERHUTANI }\end{array}$} & \multirow[b]{2}{*}{$\begin{array}{c}\begin{array}{c}\text { Ketinggian } \\
\text { tempat } \\
(\text { mdpl })\end{array} \\
\end{array}$} & \multicolumn{3}{|c|}{ Kondisi } & \multirow[b]{2}{*}{ Areal longsor } & \multirow[b]{2}{*}{$\begin{array}{c}\text { Upaya yang } \\
\text { dilakukan }\end{array}$} & \multirow[b]{2}{*}{ Pelaksana } \\
\hline & & & $\begin{array}{l}\text { Umur } \\
\text { tegakan }\end{array}$ & $\begin{array}{l}\text { Kelas } \\
\text { hutan }\end{array}$ & $\begin{array}{l}\text { Vegetasi } \\
\text { lain }\end{array}$ & & & \\
\hline 35B3 & ТВРТН & 660 & - & Pinus & Semak & Lahan Kosong & Belum ada & - \\
\hline $39 \mathrm{C1}$ & KUIV & 680 & Tua & Pinus & Palawija & Lahan Kosong & $\begin{array}{c}\text { Ditanami } \\
\text { Rumput Gajah }\end{array}$ & $\begin{array}{c}\mathrm{RPH} \\
\text { Cepoko }\end{array}$ \\
\hline $54 \mathrm{~A}$ & HLT & 1040 & Tua & Pinus & Palawija & $\begin{array}{l}\text { Belum terjadi } \\
\text { longsor }\end{array}$ & $\begin{array}{l}\text { Papan atau } \\
\text { spanduk } \\
\text { peringatan }\end{array}$ & $\begin{array}{c}\text { RPH } \\
\text { Cepoko }\end{array}$ \\
\hline $66 B$ & HLT & 1050 & Tua & Pinus & $\begin{array}{l}\text { Palawija } \\
\text { dan } \\
\text { Cincau }\end{array}$ & $\begin{array}{l}\text { Belum terjadi } \\
\text { longsor }\end{array}$ & $\begin{array}{c}\text { Ditanami } \\
\text { Rumput Gajah }\end{array}$ & $\begin{array}{c}\text { RPH } \\
\text { Cepoko }\end{array}$ \\
\hline 69A2 & KUI & 860 & Muda & Pinus & Coklat & $\begin{array}{c}\text { Belum terjadi } \\
\text { longsor }\end{array}$ & Belum ada & - \\
\hline
\end{tabular}

Keterangan: TBPTH: tidak baik untuk produksi dan tebang habis, HLT: hutan lindung terbatas, KU I: umur tegakan 1-5 tahun, dan KU IV: umur tegakan 16-20 tahun.

Longsoran aliran bahan rombakan adalah pergerakan sejumlah besar massa tanah yang didorong oleh air (Gambar 1). Kecepatan alirannya bergantung pada kemiringan lereng, volume, tekanan air dan jenis materialnya. Biasanya terjadi pada daerah-daerah berlembah curam. Selain itu, longsoran aliran bahan rombakan juga disebabkan oleh tanah bertekstur lempung. Tanah dengan tekstur tersebut apabila mengembang terus yang diakibatkan oleh hujan lebat yang diikuti oleh kenaikan berangsur-angsur tekanan air pori dan turunnya kuat geser tanah akan berakibat longsor.

Tabel 3 menunjukkan RPH Cepoko telah melakukan upaya penanganan longsor. Upaya yang dilakukan berupa mitigasi pasif dan mitigasi aktif. Mitigasi pasif tersebut berupa pemasangan papan peringatan longsor pada kawasan yang longsor (Petak 54A) dan mitigasi aktifnya adalah dengan menanam rumput gajah sebelum terjadi longsor (Petak 39C1 dan 66B).

Pada prinsipnya upaya mitigasi dapat dilakukan melalui pendekatan non struktural. Mitigasi pasif berupa pengembangan tindakan-tindakan seperti peraturan tentang bangunan (building code), tata guna lahan, tata ruang kota, pemasangan rambu dan tanda bahaya. Mitigasi aktif mencakup tindakan-tindakan yang memerlukan kontak langsung dengan penduduk yaitu melalui penyuluhan (Sutikno 1994 dalam Nursa'ban 2008). Tetapi kedua hal tersebut masih belum efektif, karena meskipun usaha tersebut telah dilakukan tetapi tetap terjadi longsor.

\section{Prioritas jenis tumbuhan lokal}

Terdapat beberapa jenis tumbuhan yang dapat mengurangi resiko erosi tanah dan berpotensi mencegah tanah longsor (Tabel 4). Berdasarkan Tabel 4 diketahui bahwa tumbuhan dapat membantu mengatasi kejadian longsor dengan dua cara yaitu, memodifikasi tanah (dalam hal menjaga kelembaban tanah) melalui proses evapotranspirasi (air hujan tidak semuanya tersimpan, tetapi akan hilang kembali melalui penguapan), dan dapat menguatkan tanah dengan akarnya (sampai kedalaman > 5 meter) (Stokes et al. 2009), kemudian menurut Van Dijk et al. (1996) bahwa tinggi tanaman dan luasnya tutupan kanopi merupakan hal utama yang juga ikut mempengaruhi tanah di bawah tegakan.

Tabel 4 Daftar jenis tumbuhan yang dapat mengurangi resiko erosi tanah dan mencegah tanah longsor

\begin{tabular}{|c|c|c|c|}
\hline No & Jenis & Peranan & Sumber \\
\hline 1. & $\begin{array}{l}\text { Kemiri (Aleurites } \\
\text { moluccana) }\end{array}$ & $\begin{array}{l}\text { Perakaran tunggang yang menembus secara dalam dengan akar yang } \\
\text { bercabang banyak }\end{array}$ & $\begin{array}{l}\text { Hardiyatmo, } \\
2006 .\end{array}$ \\
\hline 2. & $\begin{array}{l}\text { Mindi (Melia } \\
\text { azedarach) }\end{array}$ & $\begin{array}{l}\text { Perakaran tunggang yang menembus secara dalam dengan akar yang } \\
\text { bercabang banyak }\end{array}$ & $\begin{array}{l}\text { Hardiyatmo, } \\
2006 .\end{array}$ \\
\hline 3. & $\begin{array}{l}\text { Lamtoro (Leucaena } \\
\text { leucocephala) }\end{array}$ & $\begin{array}{l}\text { Perakaran tunggang yang menembus secara dalam dengan akar yang } \\
\text { bercabang banyak }\end{array}$ & $\begin{array}{l}\text { Hardiyatmo, } \\
2006 .\end{array}$ \\
\hline 4. & Jati (Tectona grandis) & $\begin{array}{l}\text { Perakaran tunggang yang menembus secara dalam dengan akar sedikit } \\
\text { bercabang }\end{array}$ & $\begin{array}{l}\text { Hardiyatmo, } \\
2006 .\end{array}$ \\
\hline 5. & $\begin{array}{l}\text { Kesambi (Schleichera } \\
\text { oleosa) }\end{array}$ & $\begin{array}{l}\text { Perakaran tunggang yang menembus secara dalam dengan akar sedikit } \\
\text { bercabang }\end{array}$ & $\begin{array}{l}\text { Hardiyatmo, } \\
2006 .\end{array}$ \\
\hline 6. & $\begin{array}{l}\text { Durian (Durio } \\
\text { zibethinus) }\end{array}$ & Dapat ditanam pada daeerah yang mengandung air dan tahan pangkas & $\begin{array}{l}\text { Hardiyatmo, } \\
2006 .\end{array}$ \\
\hline 7. & $\begin{array}{l}\text { Kaliandra (Calliandra } \\
\text { callothyrsus) }\end{array}$ & $\begin{array}{l}\text { Di Sulawesi Selatan ditanam di lereng bukit sepanjang garis kontur } \\
\text { untuk menahan tanah dan akhirnya membentuk teras alami }\end{array}$ & Icraf 2001 \\
\hline 8. & Rumput vertiver & $\begin{array}{l}\text { Perakaran dalam mencapai } 3 \mathrm{~m} \text {, sehingga dapat membantu menstabilkan } \\
\text { tanah }\end{array}$ & $\begin{array}{l}\text { Pranatasari dan } \\
\text { Beny } 2014\end{array}$ \\
\hline 9. & Pisang (Mussa sp.) & $\begin{array}{l}\text { Pisang dapat berperan sebagai pohon peneduh dengan kanopinya yang } \\
\text { lebar dan serasah yang dihasilkannya berpengaruh untuk mengendalikan } \\
\text { erosi. }\end{array}$ & $\begin{array}{l}\text { Sepúlveda et } \\
\text { al.2015 }\end{array}$ \\
\hline
\end{tabular}


Adapun jenis tanaman hasil wawancara masyarakat dan petugas KPH Lawu Ds ada 25 jenis tumbuhan yaitu cengkeh, lamtoro, kopi, mahoni, coklat, kaliandra, pisang, durian, sajang, palem, kemiri, jambu mete, cokro, kluwak, beringin, bambu, trembesi, bulu, ketapang, jati, jabon, mindi, sengon, tanjung, dan kepuh. tetapi hanya 22 jenis saja yang menurut masyarakat masih ada dan juga tumbuh, sedangkan tumbuhan sajang, cokro, dan bulu tidak tumbuh dan tidak dijumpai lagi di wilayah tersebut dan dikarenakan informasi terbatas untuk ketiga jenis tumbuhan ini sehingga sulit untuk diketahui dari famili dan jenis apa tumbuhan tersebut. Upaya mitigasi dapat dilakukan seperti mengganti jenis penggunaan lahan dari intensif ke nonintensif seperti jenis agroforestri dengan tanaman berakar dalam, transpirasi tinggi, dan tidak berpotensi mengikat air.

Jenis tumbuhan yang diperoleh dengan kesesuaiannya untuk keperluan mitigasi longsor ada 19 jenis berdasarkan persyaratan untuk mitigasi tumbuhan dengan tipe perakaran dalam, transpirasi tinggi (ditandai kemampuan menghasilkan serasah), dan tidak berpotensi mengikat air (tumbuhan dengan perakaran tunggang) dimiliki oleh tumbuhan cengkeh, lamtoro, kopi, kemiri, mahoni, coklat, kaliandra, durian, jambu mete, kluwak, beringin, trembesi, ketapang, jati, jabon, mindi, sengon, tanjung, dan kepuh.

Karena tumbuhan akan ditanam di kawasan milik Perhutani dan syarat untuk ditanamnya harus yang tidak memiliki sifat sebagai tumbuhan invasif dan memiliki sifat alelopati sehingga komposisinya berubah menjadi 18 jenis yaitu cengkeh, kopi, kemiri, mahoni, coklat, kaliandra, lamtoro, durian, jambu mete, kluwak, beringin, trembesi, ketapang, jati, jabon, sengon, tanjung, dan kepuh.

Lamtoro (Leucaena leucocephala) merupakan tumbuhan yang cepat tumbuh dan telah banyak diperkenalkan karena secara kualitas dapat menguntungkan dari sisi ekonomi seperti dapat dijadikan bahan pembuat kertas (López et al. 2010) dan pakan ternak (D'Mello dan Acamovic 1989; Garcia et al. 1996). Tetapi tumbuhan ini memiliki sifat negatif karena dapat membentuk belukar yang monospesifik padat dan mengancam tumbuhan asli (invasif), sehingga diperlukan suatu strategi dalam budidayanya seperti mengatur jarak tanam sehingga kerapatan dapat diatur dan tidak menyebabkannya menjadi semak belukar (http://www.issg.org). Prasad et al. (2011) menyebutkan bahwa dengan mengatur jarak tanam, kerapatan tanaman dapat diatur dan budidaya dari lamtoro tersebut akan meningkatkan biomasa dan diameter batang.

Penentuan prioritas jenis tumbuhan lokal untuk keperluan mitigasi longsor didasarkan atas preferensi masyarakat dan KPH dengan menggunakan beberapa kriteria, yaitu aspek ekologi, ekonomi dan sosial dari setiap jenis tumbuhan yang tumbuh di sekitar lokasi area rawan longsor.

Berdasarkan wawancara mendalam dengan beberapa responden yaitu masyarakat dan petugas KPH Lawu Ds, kemudian jenis tumbuhan tersebut dianalisis dengan metode AHP (Analitical Hierarchi Process) dengan model rating, sedangkan model rating yang diperoleh dari wawancara distrukturkan pada Gambar 2.

Berdasarkan Tabel 4 yaitu hasil wawancara diperoleh tingkat kepentingan atau bobot dari setiap kriteria yang dipertimbangkan sebagai berikut; ekologi (0.740), sosial (0.167), dan ekonomi (0.094). Responden mengatakan bahwa untuk memilih jenis vegetasi yang digunakan dalam mitigasi longsor, sebaiknya aspek ekologi yang pertama dipertimbangkan, baru aspek sosial dan terakhir aspek ekonomi. Sedangkan bobot dari setiap indikator masing-masing aspeknya adalah sebagai berikut; tumbuhan yang sesuai dengan menejemen KPH Lawu Ds (0.573), tumbuhan yang disukai masyarakat (0.129), masyarakat mengetahui cara budidayanya (0.129), tumbuhan ada harganya jika dijual (0.073), tumbuhan mudah dipasarkan (0.073), dan tumbuhan bersifat multi manfaat (0.024). Berdasarkan model rating yang diperoleh, selanjutnya setiap jenis vegetasi yang sudah diidentifikasi cocok untuk mitigasi longsor dinilai dengan model tersebut dan menghasilkan prioritas pengembangan jenisnya seperti diuraikan dalam Tabel 5.

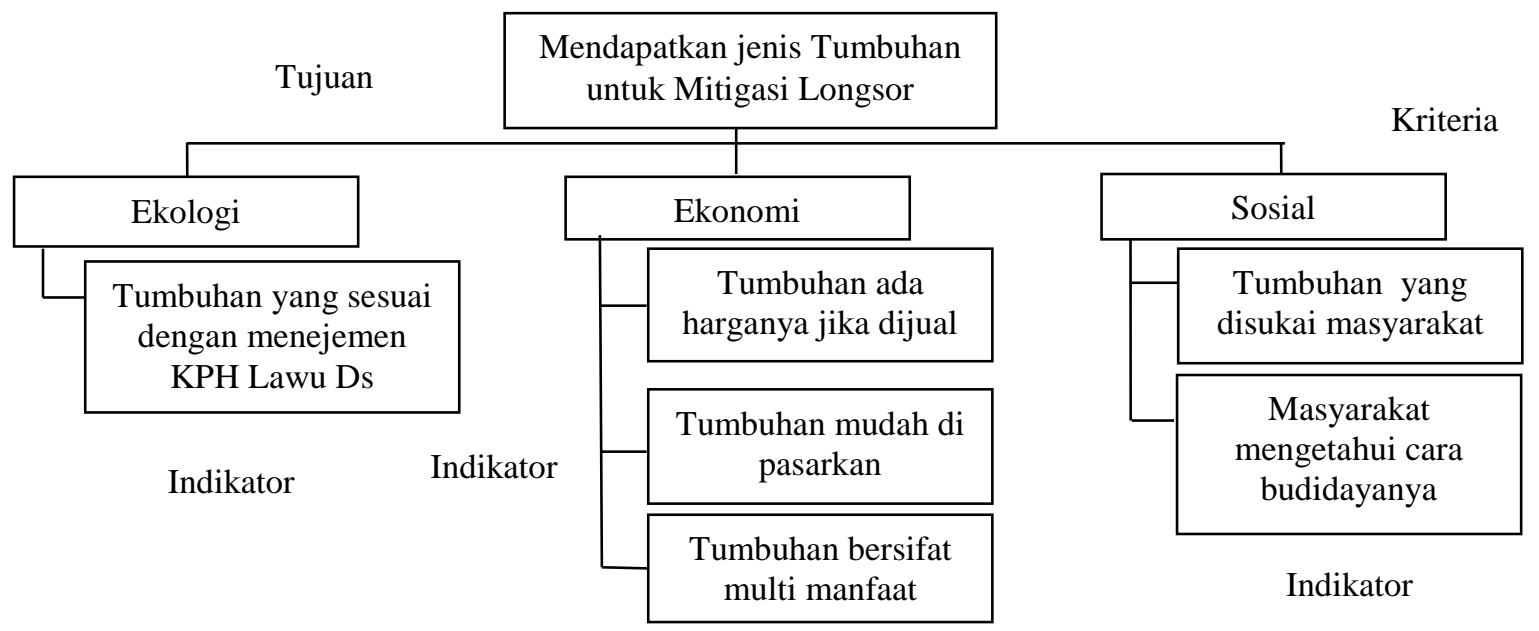

Gambar 2 Model hierarki tumbuhan lokal untuk keperluan mitigasi longsor. 
Tabel 4 Bobot dan prioritas kriteria dan indikator penyusun strategi pengembangan jenis tumbuhan lokal yang tepat untuk mitigasi longsor di KPH Lawu Ds.

\begin{tabular}{cllll}
\hline No & \multicolumn{1}{c}{ Kriteria } & Bobot & \multicolumn{1}{c}{ Indikator } & Bobot \\
\hline 1 & Ekologi & 0.740 & Tumbuhan sesuai menejemen KPH & 0.573 \\
& & & Tumbuhan ada harganya jika dijual & 0.073 \\
2 & \multirow{2}{*}{ Ekonomi } & \multirow{2}{*}{0.094} & $\begin{array}{l}\text { Tumbuhan mudah dipasarkan } \\
\text { Sumbuhan bersifat multi manfaat }\end{array}$ & 0.073 \\
& & & Tumbuat & 0.024 \\
3 & \multirow{2}{*}{ Sosial } & \multirow{2}{*}{0.167} & Tumbuhan disukai masyarakat & 0.129 \\
& & & Masyarakat tahu cara budidayanya & 0.129 \\
\hline
\end{tabular}

Berdasarkan Tabel 5 yaitu model rating penilaian jenis tumbuhan untuk mitigasi longsor, maka setiap jenis tumbuhan tersebut akan mempunyai nilai berkisar dari 0 sampai dengan 1 . Nilai yang mendekati 1 menunjukkan jenis tumbuhan tersebut makin disukai untuk dikembangkan.

\section{Teknik Budidaya dan Faktor Pembatas Tanaman}

Mitigasi bencana alam longsor secara vegetatif merupakan upaya pencegahan dan penanggulangan bencana alam dengan cara memperhatikan kondisi vegetasi yang ada di daerah terjadinya bencana longsor, meliputi pemilihan jenis vegetasi yang sesuai dan pengaturan jarak tanaman. Adapun teknik budidaya yang berperan dalam pengendalian erosi dan berpotensi mencegah tanah longsor dapat dilihat pada Tabel 6.

Faktor pembatas dalam pertumbuhan tanaman di kelima petak yaitu di petak 54A, 66B, 69A2, 35B3 dan 39C1 adalah kondisi tanah yang berlempung (Clay) dan solum tanah yang dangkal sampai sedang. Tanah yang berlempung akan sangat sulit ditembus oleh air, selain itu juga memiliki kecenderungan mudah kering oleh sinar matahari sehingga akan berakibat kekurangan air. Tanah yang dangkal juga dapat berdampak buruk pada tanaman yaitu dapat menghambat pergerakan akar dalam mencari unsur hara mineral dan air (Hardiyatmo 2006), sehingga ilustrasi teknik budidaya yang sesuai dapat dilihat pada Tabel 7.

Tabel 5 Rekapitulasi hasil gabungan dalam pemilihan alternatif jenis tumbuhan lokal yang tepat untuk mitigasi longsor di KPH Lawu Ds.

\begin{tabular}{|c|c|c|c|c|c|}
\hline \multirow[b]{2}{*}{ No } & \multicolumn{5}{|c|}{ Alternatif jenis tumbuhan lokal } \\
\hline & $\begin{array}{l}\text { Nama } \\
\text { tumbuhan }\end{array}$ & Bobot & Peringkat & \multicolumn{2}{|c|}{ Lokasi dapat ditanam } \\
\hline 1 & Cengkeh & 0.967 & 1 & \multicolumn{2}{|c|}{ KU } \\
\hline 2 & Kopi & 0.967 & 2 & \multicolumn{2}{|c|}{ KU } \\
\hline 3 & Coklat & 0.967 & 3 & \multicolumn{2}{|c|}{ KU } \\
\hline \multirow[t]{2}{*}{4} & Kaliandra & 0.586 & 4 & \multicolumn{2}{|c|}{$\mathrm{KU}$} \\
\hline & \multicolumn{5}{|c|}{ Alternatif jenis tumbuhan lokal } \\
\hline No & $\begin{array}{l}\text { Nama } \\
\text { tumbuhan }\end{array}$ & Bobot & Peringkat & \multicolumn{2}{|c|}{ Lokasi dapat ditanam } \\
\hline 5 & Lamtoro & 0.549 & 5 & \multicolumn{2}{|c|}{ TBTPH,KU } \\
\hline 6 & Durian & 0.385 & 6 & \multicolumn{2}{|c|}{ KU } \\
\hline 7 & Mahoni & 0.262 & 7 & \multicolumn{2}{|c|}{ KU } \\
\hline 8 & Kemiri & 0.231 & 8 & \multicolumn{2}{|c|}{ KU } \\
\hline 9 & Sengon & 0.228 & 9 & \multicolumn{2}{|c|}{ KU } \\
\hline 10 & Kluwak & 0.183 & 10 & \multicolumn{2}{|c|}{ ТВТРН,KU } \\
\hline 11 & Jambu Mete & 0.180 & 11 & \multicolumn{2}{|c|}{ KU } \\
\hline 12 & Kepuh & 0.028 & 12 & \multicolumn{2}{|c|}{$\mathrm{KU}$} \\
\hline \multicolumn{6}{|c|}{$\begin{array}{ll}\text { Keterangan: } & \text { TBPTH: Bagian wilayah tidak baik untuk produksi dan tebang habis, KU: Bagian wilayah untuk } \\
& \text { menghasilkan kayu, getah, dan hasil hutan lainnya. }\end{array}$} \\
\hline Pola & Deskripsi & & Perlakuan & & Sumber \\
\hline $\begin{array}{l}\text { Pagar hidup } \\
\text { berlapis }\end{array}$ & $\begin{array}{l}\text { Pagar berlapis } \\
\text { menjadikan ternak dan } \\
\text { kayu sebagai komponen } \\
\text { pokok usahatani } \\
\text { sedangkan hasil tanaman } \\
\text { palawija dan tanaman } \\
\text { pangan lainnya hanya } \\
\text { sebagai sumber } \\
\text { pendapatan tambahan } \\
\text { atau sampingan }\end{array}$ & $\begin{array}{l}\text { - Tanaman hijauan } \\
\text { (leguminosa) sepert } \\
\text { tanaman-tanaman } \mathrm{p} \\
\text { jati putih, jabon, du } \\
\text { Pepohonan dan per } \\
\text { ternak dan kayu (ba } \\
\text { dapat hidup dan ber } \\
\text { atau lahan kritis. } \\
\text { - Mulsa yang dihas } \\
\text { mengurangi runoff } \\
\text { dapat menjadi pens }\end{array}$ & $\begin{array}{l}\text { g ditanam dap } \\
\text { al, kaliandra, } \\
\text { ya seperti war } \\
\text { eranti merah, } \\
\text { adalah tanam } \\
\text { kar dan/atau k } \\
\text { engan baik pa } \\
\text { erasah tanama } \\
\text { gkutan tanah, } \\
\text { kontrol erosi. }\end{array}$ & $\begin{array}{l}\text { laman pohon } \\
\text { dan } \\
\text { lor, mimba, } \\
\text { gon. } \\
\text { hijauan } \\
\text { an) yang } \\
\text { han kering } \\
\text { at } \\
\text { ulsa tersebut }\end{array}$ & $\begin{array}{l}\text { Kinama } \text { et } \\
\text { al. 2005; } \\
\text { Tejowulan } \\
2013\end{array}$ \\
\hline
\end{tabular}




\begin{tabular}{|c|c|c|c|}
\hline Pola & Deskripsi & Perlakuan & Sumber \\
\hline Multistrata & $\begin{array}{l}\text { Pola tanam dengan } \\
\text { tanaman tahunan yang } \\
\text { ditanam disela-sela } \\
\text { tanaman pokok tahunan. } \\
\text { Pola ini dimaksudkan } \\
\text { untuk mengurangi } \\
\text { intensitas penyinaran } \\
\text { matahari, dan dapat } \\
\text { melindungi tanaman } \\
\text { pokok dari bahaya erosi } \\
\text { terutama ketika tanaman } \\
\text { pokok masih muda }\end{array}$ & $\begin{array}{l}\text { - Tumbuhan coklat dapat ditumbuhkan bersama didalam pola } \\
\text { multistrata dan sistem agroforestri kompleks dimana kanopi dari } \\
\text { coklat digabungkan dengan kanopi tumbuhan pelindungnya sehingga } \\
\text { tumbuhan pelindung (kemiri (Aleurites muluccana), jengkol } \\
\text { (Pithecellobium jiringa), petai (Perkia speciosa), kayu manis, dadap, } \\
\text { lamtoro, gamal, durian (Durio zibethinus), alpukat (Persea } \\
\text { americana), nangka (Artocarpus heterophyllus), cempedak } \\
\text { (Artocarpus integer) tersebut akan menjadi peneduh bagi coklat. } \\
\text { - Tajuk tanaman yang bertingkat menyebabkan sistem ini } \\
\text { menyerupai hutan, yang mana hanya sebagian kecil air yang } \\
\text { langsung menerpa permukaan tanah. Produksi serasah yang banyak } \\
\text { juga menjadi keuntungan tersendiri dari sistem ini. }\end{array}$ & $\begin{array}{l}\text { Subagyono } \\
\text { et al. 2003; } \\
\text { Utomo } \\
2015\end{array}$ \\
\hline $\begin{array}{l}\text { Pertanaman } \\
\text { sela }\end{array}$ & $\begin{array}{l}\text { Pertanaman campuran } \\
\text { antara tanaman tahunan } \\
\text { dengan tanaman } \\
\text { semusim. Sistem ini } \\
\text { banyak dijumpai di } \\
\text { daerah hutan atau kebun } \\
\text { yang dekat dengan lokasi } \\
\text { permukiman }\end{array}$ & $\begin{array}{l}\text { - Di beberapa wilayah hutan jati daerah Jawa Tengah, ketika pohon } \\
\text { jati masih pendek dan belum terbentuk kanopi, sebagian lahannya } \\
\text { ditanami dengan tanaman semusim berupa jagung, padi gogo, } \\
\text { kedelai, kacang-kacangan, dan empon-empon seperti jahe (Zingiber } \\
\text { officinale), temulawak (Curcuma xanthorrizha), kencur (Kaemtoria } \\
\text { galanga), kunir (Curcuma longa), dan laos (Alpinia galanga). }\end{array}$ & $\begin{array}{l}\text { Subagyono } \\
\text { et al. } 2003\end{array}$ \\
\hline $\begin{array}{l}\text { Pertanaman } \\
\text { lorong }\end{array}$ & $\begin{array}{l}\text { Sistem pertanaman } \\
\text { lorong atau alley } \\
\text { cropping adalah suatu } \\
\text { sistem dimana tanaman } \\
\text { pagar pengontrol erosi } \\
\text { berupa barisan tanaman } \\
\text { yang ditanam rapat } \\
\text { mengikuti garis kontur, } \\
\text { sehingga membentuk } \\
\text { lorong-lorong dan } \\
\text { tanaman semusim berada } \\
\text { di antara tanaman pagar } \\
\text { tersebut }\end{array}$ & $\begin{array}{l}\text { - Pada penelitian sistem pertanaman lorong dengan menggunakan } \\
\text { tiga jenis legum yang ditanam dua strip tiap baris, dilaporkan bahwa } \\
\text { pada tahun kedua penanaman Flemingia congesta sudah terlihat } \\
\text { adanya pembentukan teras alami dengan tinggi tampingan sekitar } 25 \\
\mathrm{~cm} \text {, lebih tinggi dibandingkan pada tanaman Calliandra calothyrsus } \\
\text { maupun Tephrosia volgelli. Hal ini disebabkan oleh pengaruh } \\
\text { kerapatan tanaman serta produksi hijauan Flemingia congesta yang } \\
\text { mampu menahan partikel tanah lebih baik dibandingkan Calliandra } \\
\text { maupun Tephrosia. } \\
\text { - Penelitian alley cropping terhadap erosi Haplothrox Citayam } \\
\text { menyimpulkan bahwa dari beberapa perlakuan yang diberikan } \\
\text { ternyata Flemingia congesta dengan jarak alley } 6 \text { m dan ditanam dua } \\
\text { baris cukup efektif menahan erosi dan aliran permukaan. }\end{array}$ & $\begin{array}{l}\text { Subagyono } \\
\text { et al. } 2003\end{array}$ \\
\hline $\begin{array}{l}\text { Kebun } \\
\text { campuran }\end{array}$ & $\begin{array}{l}\text { Kebun campuran ini } \\
\text { mampu mencegah erosi } \\
\text { dengan baik karena } \\
\text { kondisi penutupan tanah } \\
\text { yang rapat sehingga } \\
\text { butiran air hujan tidak } \\
\text { langsung mengenai } \\
\text { permukaan tanah. } \\
\text { Kerapatan tanaman juga } \\
\text { mampu mengurangi laju } \\
\text { aliran permukaan. Hasil } \\
\text { tanaman lain di luar } \\
\text { tanaman semusim } \\
\text { mampu mengurangi } \\
\text { risiko akibat gagal panen } \\
\text { dan meningkatkan nilai } \\
\text { tambah bagi petani. }\end{array}$ & $\begin{array}{l}\text { - Pertanaman sela tumbuhan serealia yang digabungkan dengan } \\
\text { pertanaman pagar dari lamtoro (Leucaena leucocephala) dan } \\
\text { penambahan pupuk dapat meningkatkan penggunaan air hujan secara } \\
\text { efisien dan meningkatkan stabilitas dalam sistem pertanian tadah } \\
\text { hujan. } \\
\text { - Tanaman yang ditanam adalah tanaman tahunan yang dimanfaatkan } \\
\text { hasil buah, daun, dan kayunya. Kadang-kadang juga ditanam dengan } \\
\text { tanaman semusim. Apabila proporsi tanaman semusim lebih besar } \\
\text { daripada tanaman tahunan, maka lahan tersebut disebut tegalan. }\end{array}$ & $\begin{array}{l}\text { Subagyono } \\
\text { et al. 2003; } \\
\text { Sileshi } \\
2011\end{array}$ \\
\hline $\begin{array}{l}\text { Tumpang } \\
\text { sari }\end{array}$ & $\begin{array}{l}\text { Pertanaman majemuk } \\
\text { yang merupakan salah } \\
\text { satu bagian dalam pola } \\
\text { tanam pada dasarnya } \\
\text { merupakan sistem } \\
\text { dimana satu bidang olah } \\
\text { ditanami lebih dari satu } \\
\text { jenis tanaman pangan. }\end{array}$ & $\begin{array}{l}\text { - Pada tahun 1974, hasil penelitian IRRI membuktikan bahwa } \\
\text { populasi hama penggerek jagung (Ostrinia nubilalis) pada } \\
\text { penanaman tumpang sari antara jagung dan kacang tanah berada } \\
\text { dalam jumlah yang lebih kecil dibandingkan dengan jumlah populasi } \\
\text { hama tersebut pada saat jagung ditanam secara monokultur. Dengan } \\
\text { penerapan pertanaman majemuk, penutupan tanah akan lebih rapat } \\
\text { sehingga mampu melindungi tanah dari pukulan air hujan secara } \\
\text { langsung dan menahan aliran permukaan. }\end{array}$ & $\begin{array}{l}\text { Subagyono } \\
\text { et al. } 2003\end{array}$ \\
\hline
\end{tabular}


Tabel 7 Ilustrasi teknik budidaya yang sesuai untuk mitigasi longsor

\begin{tabular}{|c|c|c|c|c|c|}
\hline $\begin{array}{l}\text { Petak } \\
\text { tanam }\end{array}$ & $\begin{array}{c}\text { Tenik budidaya/ } \\
\text { pola tanam }\end{array}$ & Kondisi petak & $\begin{array}{l}\text { Kompoisi jenis } \\
\text { tanaman }\end{array}$ & Jarak tanam $(\mathrm{m})$ & $\begin{array}{c}\text { Perlakuan teknik } \\
\text { sipil } \\
\end{array}$ \\
\hline $35 \mathrm{~B} 3$ & Pertanaman lorong & $\begin{array}{l}\text { Tanah kosong, } \\
\text { curam }\end{array}$ & $\begin{array}{l}\text { Cengkeh, Cengkeh (ce) } \\
+ \text { Durian }(\mathrm{du}), \text { Cengkeh } \\
(\mathrm{ce})+\text { Kopi (ko) }\end{array}$ & $\begin{array}{l}8 \times 8 ; 8 \times 8(\mathrm{ce}) \text { dan } 10 \\
\times 10(\mathrm{du}) ; 8 \times 8(\mathrm{ce}) \\
\text { dan } 5 \times 2.5(\mathrm{ko})\end{array}$ & $\begin{array}{l}\text { Dibuat teras } \\
\text { mengikuti kontur }\end{array}$ \\
\hline $35 \mathrm{~B} 3$ & Pertanaman lorong & $\begin{array}{l}\text { Tanah kosong, } \\
\text { sangat curam }\end{array}$ & Lamtoro & $3 \times 0.75$ & Ditanam rapat \\
\hline 69A2 & Pagar hidup & $\begin{array}{l}\text { Pinus tanaman } \\
\text { muda, curam }\end{array}$ & Kaliandra & $\begin{array}{l}\text { Disesuaikan jarak } \\
\text { tanam di KPH }\end{array}$ & $\begin{array}{l}\text { Dibuat teras } \\
\text { mengikuti kontur }\end{array}$ \\
\hline 69A2 & Tumpang sari & $\begin{array}{l}\text { Pinus tanaman } \\
\text { muda, sangat } \\
\text { curam }\end{array}$ & Pinus & $\begin{array}{l}\text { Disesuaikan jarak } \\
\text { tanam di KPH }\end{array}$ & Ditanam rapat \\
\hline $39 \mathrm{C} 1$ & $\begin{array}{l}\text { Kombinasi pagar } \\
\text { hidup dengan } \\
\text { pertanaman sela }\end{array}$ & $\begin{array}{l}\text { Pinus kerapatan } \\
\text { jarang, curam }\end{array}$ & $\begin{array}{l}\text { Kopi, } \\
\text { Kopi(ko)+Lamtoro(la), } \\
\text { Kopi(ko)+Durian(du) }\end{array}$ & $\begin{array}{l}5 \times 2.5 ; 5 \times 2.5(\mathrm{ko}) \text { dan } \\
3 \times 0.75(\mathrm{la}) ; 5 \times \\
2.5(\mathrm{ko}) \text { dan } 10 \times 10(\mathrm{du})\end{array}$ & $\begin{array}{l}\text { Dibuat teras } \\
\text { mengikuti kontur }\end{array}$ \\
\hline $39 \mathrm{C} 1$ & Tumpang sari & $\begin{array}{l}\text { Pinus kerapatan } \\
\text { jarang, sangat } \\
\text { curam }\end{array}$ & Pinus & $\begin{array}{l}\text { Disesuaikan jarak } \\
\text { tanam di KPH }\end{array}$ & Ditanam rapat \\
\hline $54 \mathrm{~A}$ & Kebun campuran & $\begin{array}{l}\text { Pinus kerapatan } \\
\text { sedang, curam }\end{array}$ & $\begin{array}{l}\text { Coklat; Coklat } \\
(\mathrm{co})+\text { Durian }(\mathrm{du})\end{array}$ & $\begin{array}{l}3 \times 3 ; 3 \times 3(\mathrm{co}) \text { dan } 10 \\
\times 10(\mathrm{du})\end{array}$ & $\begin{array}{l}\text { Dibuat teras } \\
\text { mengikuti kontur }\end{array}$ \\
\hline $66 \mathrm{~B}$ & Tumpang sari & $\begin{array}{l}\text { Pinus kerapatan } \\
\text { sedang, sangat } \\
\text { curam }\end{array}$ & Pinus & $\begin{array}{l}\text { Disesuaikan jarak } \\
\text { tanam di KPH }\end{array}$ & Ditanam rapat \\
\hline $66 \mathrm{~B}$ & Tumpang sari & $\begin{array}{l}\text { Pinus kerapatan } \\
\text { tinggi, curam }\end{array}$ & Pinus & $\begin{array}{l}\text { Disesuaikan jarak } \\
\text { tanam di KPH }\end{array}$ & $\begin{array}{l}\text { Dibuat teras } \\
\text { mengikuti kontur }\end{array}$ \\
\hline
\end{tabular}
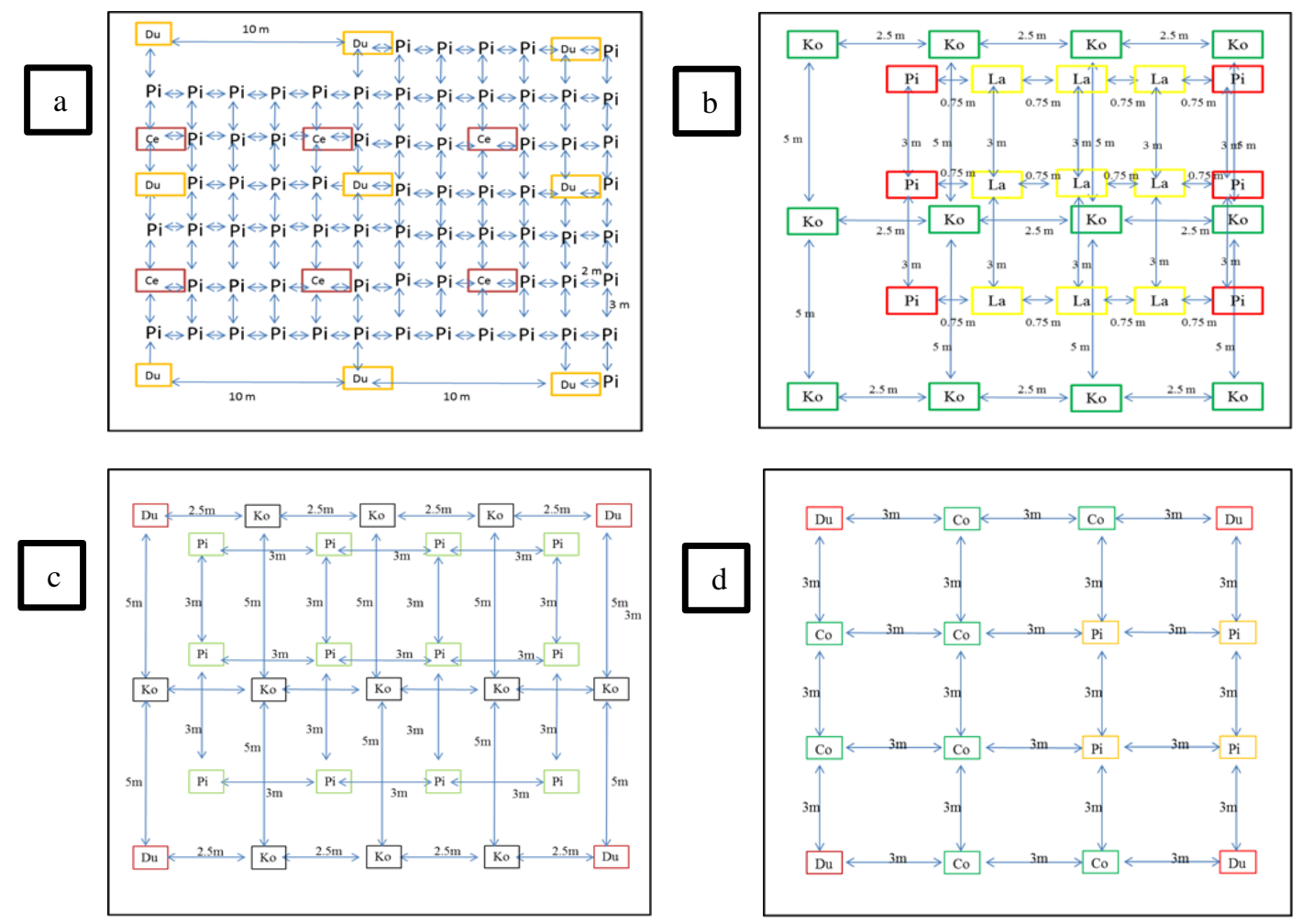

a). Pertanaman lorong dengan komposisi cengkeh $(\mathrm{Ce})+$ durian $(\mathrm{Du})$; Jarak tanam 8x8 (Ce) + 10 x $10(\mathrm{Du})$

b). Kombinasi pagar hidup dengan pertanaman sela dengan komposisi kopi (Ko) + Lamtoro (La); Jarak tanam 5 x 2.5 $(\mathrm{Ko})+3 \times 0.75(\mathrm{La})$

c). Kombinasi pagar hidup dengan pertanaman sela dengan komposisi kopi $(\mathrm{Ko})+$ durian $(\mathrm{Du})$; Jarak tanam $5 \times 2.5$ $(\mathrm{Ko})+10 \times 10(\mathrm{Du})$

d). Kebun campuran dengan komposisi coklat (Co) + durian (Du); Jarak tanam 3 × $3(\mathrm{Ko})+10 \times 10(\mathrm{Du})$ 


\section{Pola tanam dan jarak tanam}

Pola tanam adalah sistem pengaturan waktu tanam dan jenis tanaman sesuai dengan iklim, kesesuaian tanah dengan jenis tanaman, luas lahan, ketersediaan tenaga, modal, dan pemasaran. Pola tanam berfungsi meningkatkan intensitas penutupan tanah dan mengurangi terjadinya erosi (Subagyono et al. 2003).

Jarak tanam ditentukan oleh kerapatan tajuk. Tanaman bertajuk tinggi ditanam di antara baris tanaman, dan yang bertajuk rendah ditanam di bawah tanaman bertajuk sedang (Herwanti 2012). Karena tanaman bertajuk rendah tidak ada, sehingga dalam penelitian untuk tumbuhan tajuk tinggi seperti kaliandra, durian, dan lamtoro ditanam di antara baris tanaman tajuk sedang seperti cengkeh, kopi, dan coklat maka ilustrasi jarak tanam tersebut dapat dilihat pada Gambar 3.

\section{SIMPULAN}

Jenis tumbuhan lokal prioritas yang tepat dalam upaya pencegahan dan mitigasi longsor di kawasan rawan longsor KPH Lawu Ds berdasarkan persepsi masyarakat dan petugas KPH Lawu Ds adalah cengkeh, kopi, coklat, kaliandra, lamtoro, durian, mahoni, kemiri, sengon, kluwak, jambu mete, dan kepuh. Bentuk dan pola budidayanya yang sesuai untuk diterapkan di RPH Cepoko adalah pertanaman lorong, pagar hidup, kombinasi pagar hidup dengan pertanaman sela, dan kebun campuran.

\section{SARAN}

Kepada RPH Cepoko disarankan, dalam pengembangan teknik mitigasi longsor, menggunakan tumbuhan dengan jenis tanamannya cengkeh, kopi, coklat, kaliandra, durian, dan lamtoro; selain tanaman pokoknya yaitu pinus. Jarak tanam yang lebar sebaiknya dihindari karena akan mempengaruhi kerapatan vegetasi sehingga proses pelapukan fisik akan cepat dan mendukung terjadinya longsor. Untuk penelitian selanjutnya perlu dilakukan pendugaan kekuatan akar dari setiap jenis tumbuhan lokal yang diperoleh terhadap kelerengan.

\section{UCAPAN TERIMA KASIH}

Ucapan terima kasih dan penghargaan kami sampaikan kepada Pemerintah Provinsi Jawa Barat atas beasiswa yang diberikan, Perum Perhutani Divisi Regional II Jawa Timur, dan Pusat Pengkajian Perencanaan dan Pengabdian Kepada Masyarakat Institut Pertanian Bogor (P4W IPB) yang telah mengakomodasi biaya perjalanan dan mengkoordinir segala keperluan selama penelitian dilakukan.

\section{DAFTAR PUSTAKA}

Arsyad S. 2010. Konservasi Tanah \& Air. Bogor (ID): IPB Press.

Asdak C. 2003. Faktor Hutan, Geomorfologi, dan Anomali Iklim pada Bencana Longsor di Hulu DAS Cimanuk. Prosiding Semiloka Mitigasi Bencana Longsor Di Kabupaten Garut. Pemerintah Kabupaten Garut.

Bray. 1986. Leucaena in Northern Australia. Forest Ecol and Management. 16:345-354.

[BNPB] Badan Nasional Penanggulangan Bencana. Data kejadian Tanah longsor 2006-2015 [Internet]. [diunduh 23 Desember 2015]. Tersedia pada: http://dibi.bnpb.go.id.

Dibyosaputro S. 1999. Longsor lahan di Daerah Kecamatan Samigaluh. Kabupaten Kulon Progo Daerah Istimewa Yogyakarta. [Majalah Geografi Indonesia]. Yogyakarta (ID). Universitas Gadjah Mada.

Djaenudin et al. 2003. Petunjuk Teknis Evaluasi Lahan untuk Komoditas Pertanian. Bogor (ID): Balai Penelitian Tanah, Puslitbangtanak. Badan Penelitian dan Pengembangan Pertanian. DinasPertanian.

D'Mello JPF dan Acamovic T. 1989. Leucaena leucocephala in Poultry Nutrition -A Review. Animal Feed Science and Technology. 26: 1-28.

Garcia et al. 1996. The nutritive value and forage productivity of Leucaena leucocephala. Animal Feed Science Technology. 60: 29-41.

Hadiwijaya T. 1983. Cengkeh, Data dan Petunjuk ke arah Swasembada. Jakarta: PT Gunung Agung.

Hardiyatmo HC. 2006. Penanganan Tanah Longsor dan Erosi. Yogyakarta (ID): Gadjah Mada University Press.

Herwanti S. 2012. Optimalisasi Pemanfaatan Lahan Hutan Kemasyarakatan Desa Ngarip Kecamatan Ulu Belu Kabupaten Tanggamus. [Tesis]. Bogor (ID): Institut Pertanian Bogor.

[ICRAF 2001] International Centre for Research in Agroforestry. Produksi dan pemanfaatan kaliandra (Calliandra calothyrsus): Pedoman lapang. Bogor (ID): ICRAF.

[ISSG] Invasive Species Specialis Group. Global Invasive Species Data Base [Internet]. [diunduh 10 maret 2015]. Tersedia pada: http://www.issg.org.

Kinama et al. 2005. Evaporation from soils below sparse crops in contour hedgerow agroforestry in semi-arid Kenya. Agricultural and Forest Meteorology. 130: 149-162.

Kurnia U, Sudirman H , Kusnadi H. 2005. Rehabilitasi dan Reklamasi Lahan Terdegradasi. Bogor (ID): Puslittanak. Badan Penelitian dan Pengembangan Pertanian Departemen Pertanian.

Loilatu I. 2006. Analisis Pengembangan perkebunan Kakao Rakyat di Kabupaten Buru Provinsi Maluku. [Tesis]. Bogor (ID). Institut Pertanian Bogor.

López et al. 2010. Leucaena diversifolia a new raw material for paper production by soda-ethanol pulping process. Chemical Engineering Research and Design. 88: 1-9. 
Najiyati S, Danarti. 2004. Kopi : Budidaya dan Penanganan Lepas Panen. Seri Pertanian. Jakarta : Penebar Swadaya.

Normaniza dan Barakbah. 2011. The effect of plant succession on slope stability. Ecol Enginring. 37: 139-147.

Nursa'ban. 2008. Pemetaan Daerah Longsor Lahan dalam Upaya Mitigasi Bencana Alam. Geomedia. 6 : 2.

Pranatasari DS dan Beny H. 2014. Evaluasi Pertumbuhan Tanaman Konservasi Pasca Erupsi Merapi. Pembaruan Silvikultur untuk Mendukung Pemulihan Fungsi Hutan menuju Ekonomi Hijau Prosiding Seminar Nasional Silkultur II; 28-29 Agustus 2014. Yogyakarta, Indonesia. Yogyakarta (ID): Universitas Gadjah Mada. hlm 390-395.

Prasad et al. 2011. Optimum stand density of Leucaena leucocephala for wood production in Andhra Pradesh, Southern India. Biomass and bioenergy. 35: 227-235.

Ruhnayat A. 2002. Memproduktifkan Cengkih, Tanaman Tua dan Tanaman Terlantar. Jakarta (ID): Penebar Swadaya.

Sepúlveda et al. 2015. Soil erosion and erosion thresholds in an agroforestry system of coffee (Coffea arabica) and mixed shade trees (Inga spp and Musa spp) in Northern Nicaragua. Agriculture, Ecostm and Envirmnt. 210: 25-35.

Sileshi GW. 2011. Integration of legume trees in maizebased cropping systems improves rain use

efficiency and yield stability under rain-fed agriculture. Agricultural Water Management. 98: 1364-1372.

Stokes et al. 2009. Desirable Plant Root Traits for Protecting Natural and Engineered Slopes Against Landslides. Plant Soil. 324: 1-30

Subagyono et al. 2003. Teknik Konservasi Tanah secara Vegetatif. Bogor (ID): Balai Penelitian Tanah.

Tejowulan S. 2013. Pagar Hidup Berlapis: Filosofi dan Best Practice Konservasi Vegetatif. Meningkatkan Ketahanan Pangan serta Mencegah Kekeringan dan Kelangkaan Air. Prosiding Seminar Nasional VII Masyarakat Konservasi Tanah Indonesia; 6-8 November 2013. Palembang, Indonesia. Palembang (ID): BPDAS Musi. hlm 352-360.

Utomo B. 2015. Environmental performance of cocoa production from monocultureand agroforestry systems in Indonesia. Journal of Cleaner Production, siap terbit.

Van Dijk PM, Kwaad F, Klapwijk M. 1996. Retention of water and sediment by grass strips. Hydrol. Processes. 10: 1069-1080. 